\title{
The Copenhagen School Goes Global: Securitisation in the Non-West
}

\author{
Saloni Kapur \\ Department of Politics, Philosophy and Religion, County South, Lancaster University, \\ Lancaster, LA1 4YQ, United Kingdom \\ s.kapurı@lancaster.ac.uk \\ Simon Mabon \\ Department of Politics, Philosophy and Religion, County South, Lancaster University, \\ Lancaster, LA1 4YQ, United Kingdom \\ s.mabon@lancaster.ac.uk
}

The theme of the International Studies Association's 2015 Annual Convention was "Global International Relations and Regional Worlds," a theme that highlighted what Amitav Acharya and Barry Buzan (2017) refer to as "the American and Western dominance of [International Relations].” Acharya and Buzan's (2017) contention is that whereas International Relations (IR) continues to refer to Western theoretical approaches and history, the world is moving into a phase in which Western dominance is on the decline, suggesting that it is time for IR to incorporate not just non-Western ideas and histories, but also a more holistic, global understanding of IR. At the same time, Acharya and Buzan (2017) argue that their advocacy of a Global IR accepts the mainstream theories of IR, but challenges them "to accept the ideas, experiences and insights from the non-Western world" and "expects them to give due recognition to the places, roles, and contributions of non-Western peoples and societies.”

Acharya and Buzan's work on non-Western and Global IR provides the ideological foundation for this special issue on Securitisation in the Non-West. Securitisation theory, or the Copenhagen School of IR, is increasingly being applied to cases outside the Western world to comprehend the role played by discourse and political actors in constructing something as a security threat (Acharya and Buzan 2017). 
In addition, a number of scholars have taken on the task of critically analysing securitisation theory's success in satisfactorily explaining security dynamics outside the West, and various suggestions have been made as to how the theory could be tweaked or broadened to allow for more accurate representations of security in undemocratic, illiberal and other non-Western settings.

Claire Wilkinson (2007), for instance, uses the case of Kyrgyzstan to posit that securitisation theory as put forward by the Copenhagen School is unable to sufficiently account for developments beyond the West for two reasons: First, she asserts, the theory takes it for granted "that European understandings of society and the state are universal." Wilkinson opines that theorists within the Copenhagen School must explicitly question normative concepts such as state and society. Secondly, the theory's emphasis on the speech act may be unsuited to non-Western contexts where limitations to speech exist, and where securitisation may take place through other means, including action. She criticises the linear construction of a speech act leading to an exceptional measure, stating that where speech is constrained, an extraordinary action could precede the speech act.

For Martin Holbraad and Morten Axel Pedersen (2012), revolutionary Cuba provides a case of a non-liberal non-Western state where the liberal assumptions underpinning securitisation theory come into relief. While securitisation theory assumes normal politics to be clearly distinct from emergency politics, the liberal view perceives revolutionary regimes to be in a permanent state of emergency and, therefore, in a continuous state of securitisation where extra-political means are the norm. However, Holbraad and Pedersen point out, the liberal distinction between the state and society collapses in a revolutionary ontology, with revolutionary states assuming 
themselves to be the people. Thus, rules and exceptions cease to exist for a revolutionary state because the state is society. This renders problematic the Copenhagen School's assumption of a normal state of politics that can be distinguished from exceptional measures.

A third critique of securitisation theory has been carried out by Maja Touzari Greenwood and Ole Wæver (2013), who test the theory in the context of Egypt during the Arab Spring. The Arab Uprisings separated regimes from societies in a number of states, toppling previously embedded authoritarian regimes in Tunisia, Egypt, Libya, and Yemen. In other states, regimes framed protesting groups as existential threats, reconstructing the nature of political organisation amidst the conflation of domestic and regional, normative and geopolitical agendas. Greenwood and Wæver find that the theory assumes a basic level of stability and cannot therefore be applied to exceptional situations where there is no such thing as normal politics. They argue that the Egyptian revolution was such an exceptional situation and that this can be understood to be a Western bias in the theory, because Western states no longer encounter such exceptional situations.

In a time where state-society relations have frayed, amidst parabolic pressures from globalising forces and indigenous resistance to such forces, the need to offer context-specific explorations that are not solely based upon approaches predicated upon Western ontologies appears to be of paramount importance. Yet whilst the desire to move beyond Western approaches to IR is commendable, we must be careful not to throw the proverbial baby out with the bathwater.

Stemming from a workshop organized by the Richardson Institute and held at Lancaster University in the summer of 2017, this special issue seeks to engage with the 
application of processes of securitisation in a number of different non-Western contexts. With this in mind, across eight chapters and responses, the special issue tests the application of securitisation theory in a number of non-Western contexts. In the first article, Clara Eroukhmanoff (2018) introduces the concept of indirect speech acts, using the case of the securitisation of Islam in the United States. In the second article, Mona Kanwal Sheikh (2018a) explores the role of securitisation in engaging with Islamist violence, with a focus upon how securitisation can be used to capture the narrative structure of such violence. By engaging with empirical examples, Sheikh seeks to open the problems of an ontological nature stemming from Western-centrism with regard to both the application and design of the theory. In response, Saloni Kapur (2018b) focuses upon the importance of political realities, which can facilitate a greater and more accurate awareness of context specific instances of securitisation, whilst also stressing that the conflation of religion and politics does not necessarily result in securitisation.

In the third article, Simon Mabon (2018a) considers the application of securitisation efforts in the Middle East, looking at Saudi Arabia and Bahrain. Mabon argues that amidst a complex and shared normative environment, securitisation processes often transcend state borders and thus have both intended and unintended consequences beyond state boundaries. Hence, concepts of the audience require greater theorisation. In response, John Gledhill (2018a) teases out aspects of the liberal ontology that Mabon focuses upon, whilst also placing emphasis upon colonial legacies and their impact upon the idea of 'normality'.

The fourth article by Kapur (2018a) engages with the securitisation of Pakistan by Indian actors, with a particular focus upon the so-called 'Line of Control'. Kapur argues that securitisation moves in India constitute a 'two-act play', which challenge the 
linear aspects of securitisation processes understood in a Western context. In response, Sheikh (2018b) posits that whilst this is a classical approach to understanding securitisation it also allows for a focus upon the audience and the importance of popularity.

The fifth article by Edwin Ezeokafor and Christian Kaunert (2018) looks at the role of securitisation in Africa and the nexus between securitisation and neopatrimonialism. Ezeokafor and Kaunert use securitisation as a mechanism through which relations between leaders (elites) and societies can be better understood, arguing that a greater level of context and better synthesis between securitisation and neopatrimonialism is required for an accurate understanding of political life across Africa.

The sixth article by Mark Lacy and Daniel Prince (2018b) considers hypersecuritisation and the construction of cyber securitization, moving beyond territorial and spatial dimensions. Lacy and Prince suggest that the speed of hyper-securitisation and technological change requires the re-examination of the spatial dynamics that shape policy, wherein risk and (un)intended consequences collapse into planning. In response, Juha Vuori (2018b) stresses the importance of focussing upon core values at the heart of both political projects and hyper-securitisation, which allows for a discussion of difference and also intent.

The seventh article by Vuori (2018a) explores Chinese efforts 'to prevent the securitization of China's rise in the US'. In doing this, Vuori draws upon ideas of desecuritisation within Chinese foreign policy towards the major powers, contributing not only to debates on (de)securitisation but also to understandings of Chinese foreign policy. In response, Lacy and Price (2018a) consider the extent to which desecuritisation can be viewed as a tool of deception, suggesting that to get a more nuanced 
understanding of events - and indeed Chinese foreign policy - we should focus more upon infrastructural developments, where deeds reveal more than words.

In the final article, Gledhill (2018b) considers how securitisation can aid understanding of political life in Latin America, with a particular focus upon Brazil and Mexico. Gledhill argues that amidst the neoliberal agenda, political and social life has been securitised amidst the rise of 'political mafias' that have simultaneously become both guardians of order and victims of systems. In response, Mabon (2018b) suggests that this approach offers a powerful mechanism through which political and social life can be better understood.

Together, these articles highlight an array of areas for further exploration when taking securitisation theory beyond its Western domain. Whilst we should be careful not to repudiate all aspects of the theory in its application outside the Western world, it is clear that greater nuance is required beyond the West. This process has sought to identify areas through which the 'shackles of Westphalia' can be removed, creating space for further ontological and epistemological study, whilst retaining the utility of the Copenhagen School's approach. 


\section{References}

Acharya, Amitav, and Barry Buzan. 2017. "Why is There No Non-Western International Relations Theory? Ten Years on." International Relations of the Asia-Pacific 17, no. 3: 34170. Accessed December 20, 2017. http://dx.doi.org/ 10.1093/irap/lcxoo6.

Eroukhmanoff, Clara. 2018. “It's Not a Muslim Ban!' Indirect Speech Acts and the Securitisation of Islam in the US Post-9/11." Global Discourse 8, no. 1.

Ezeokafor, Edwin, and Christian Kaunert. 2018. "Securitization outside of the West: Conceptualizing the Securitization-Neopatrimonialism Nexus in Africa." Global Discourse 8, no. 1.

Gledhill, John. 2018a. "Review of Simon Mabon 'Once the Genie's out of the Bottle: Securitization in the Contemporary Middle East.” Global Discourse 8, no. 1.

———. 2018b. "Securitization, Mafias and Violence in Brazil and Mexico." Global Discourse 8, no. 1.

Greenwood, Maja Touzari, and Ole Wæver. 2013. "Copenhagen-Cairo on a Roundtrip: A Security Theory Meets the Revolution." Security Dialogue 44, no. 5-6: 485-506. Accessed December 20, 2017. http://dx.doi.org/10.1177/o967010613502573.

Holbraad, Martin, and Morten Axel Pedersen. 2012. "Revolutionary Securitization: An Anthropological Extension of Securitization Theory." International Theory 4, no. 2 (July): 165-97. Accessed December 20, 2017. https://doi.org/10.1017/S1752971912000061.

Kapur, Saloni. 2018a. "From Copenhagen to Uri and across the Line of Control: India's 'Surgical Strikes' as a Case of Securitisation in Two Acts. Global Discourse 8, no. 1.

- _ . 2018b. "Review of 'Recursion or Rejection? Securitization Theory Faces Islamist Violence and Foreign Religions,' by Mona Kanwal Sheikh.” Global Discourse 8, no. 1.

Lacy, Mark, and Daniel Prince. 2018a. "China and Discourses of Desecuritization: A Reply to Vuori." Global Discourse 8, no. 1.

Discourse 8, no. 1.

Mabon, Simon. 2018a. "Existential Threats and Regulating Life: Securitization in the Contemporary Middle East." Global Discourse 8, no. 1.

___. 2018b. "Sovereign Implications of Securitisation Work." Global Discourse 8, no. 1. 
Sheikh, Mona Kanwal. 2018a. "Recursion or Rejection? Securitization Theory Faces Islamist Violence and Foreign Religions.” Global Discourse 8, no. 1.

——_. 2018b. "Securitization Analysis beyond its Power-Critique." Global Discourse 8, no. 1.

Vuori, Juha Antero. 2018a. "Let's Just Say We'd Like to Avoid Any Great Power Entanglements: Desecuritization in Post-Mao Chinese Foreign Policy towards Major Powers." Global Discourse 8, no. 1.

———. 2018b. “The Politics of Securitized Technology." Global Discourse 8, no. 1.

Wilkinson, Claire. 2007. "The Copenhagen School on Tour in Kyrgyzstan: Is Securitization Theory Useable outside Europe?" Security Dialogue 38, no. 1: 5-25. Accessed December 20, 2017. http://dx.doi.org/ 10.1177/o967010607075964. 